\title{
PERSEKUTUAN MURID-MURID KRISTUS: Hidup Yang Berkembang Menuju Kesempurnaan
}

\author{
Alexius Dwi Widiatna \\ STKIP Widya Yuwana \\ awidiatna@gmail.com
}

\begin{abstract}
Being a disciple of Christ is a gift of a special Christian vocation. A true disciple of Christ is required to follow Jesus bravely denying himself, taking up his cross every day, and following Jesus. A disciple of Christ is a human being's community, who is called to always be united with Jesus and love others. In his life, a disciple of Christ is required to imitate and follow in the footsteps of Christ toward the perfection of life like Jesus who reached the perfection of His life by dying on the cross. A disciple becomes perfect when he unites himself with Christ totally, follows Christ wherever he walks, follows each of his steps, and always constantly learns from him under the guidance of the Holy Spirit.
\end{abstract}

Keywords: Discipleship, Perfection, Following Christ

\section{PENDAHULUAN}

Sang Guru Agung, Yesus Kristus telah memanggil orang-orang pilihanNya untuk menjadi murid-murid-Nya yang akan melanjutkan karya keselamatanNya di dunia ini. Murid-murid yang berasal dari berbagai latar belakang keluarga, sosial ekonomi, pekerjaan dikumpulkan untuk hidup bersama-sama Sang Guru selama tiga tahun lamanya. Mereka hidup bersama Yesus, menyaksikan dan mengalami hidup bersama Yesus. Pelan-pelan, bahkan sangat lamban mereka mengenal Yesus dan menjalin hubungan personal dengan Yesus, Sang Guru. Selain itu, kebersamaan para murid bersama Yesus juga menjadi kurikulum tersendiri untuk membangun dan menumbuhkembangkan semangat persekutuan antar para murid dalam mengikuti Yesus. Selain relasi pribadi dengan Yesus yang membawa konsekuensi menyangkal diri, memikul salib setiap hari, para murid sekaligus dibentuk menjadi insan persekutuan, yang harus saling mengasihi satu sama lain, mengasihi sesama seperti diri sendiri, dan bersama-sama mengejar kesempurnaan hidup di dunia ini.

Dalam artikel ini penulis mengajak para pembaca untuk merefleksikan panggilan menjadi murid Sang Guru Agung, Yesus Kristus. Maka pertama-tama, penulis mengundang pembaca untuk menjawab pertanyaan apa artinya mengikuti Yesus dengan menjadi murid Yesus. Selanjutnya, penulis mengajak merenungkan mengapa dan bagaimana Yesus Sang Guru mengurbankan diri-Nya secara total 
dan sempurna di kayu salib. Akhirnya, para murid Yesus dituntut untuk menyerupai Yesus: bagaimana mengembangkan hidup di dunia ini menuju kesempurnaan seperti yang diteladankan oleh Sang Guru.

\section{MENGIKUTI KRISTUS: MENJADI MURID KRISTUS}

Yesus, Sang Guru Agung secara unik memanggil murid-murid-Nya yang berasal dari berbagai latar belakang untuk melanjutkan karya penyelamatan dan pewartaan Injil di dunia. Yesus memanggil, memilih, dan hidup bersama dua belas murid untuk melakukan pendidikan, pembinaan, dan pelatihan menjadi guru dan pemimpin jemaat yang handal dan kompeten. Hal ini dikatakan olehTanner (2013:43), “Jesus masterfully worked with the original twelve disciples, calling them from their rather mundane way of life to transform them into fearless leader who would lay the foundation of the church in the first century". Yesus dengan sangat piawai bekerja dengan dua belas rasul awali, memanggil mereka dari cara hidup duniawi mereka mentransformasikan mereka menjadi pemimpin gagah berani, yang meletakkan fondasi Gereja pada abad pertama. Yesus adalah seorang Guru yang benar-benar mengenal masing-masing pribadi murid-murid-Nya, sehingga Dia paham betul bagaimana mendidik murid-muridNya dengan memberi instruksi, kapan harus membangun kesadaran para murid, membangkitkan semangat, menegur dengan keras, maupun meluruskan pandangan dan sikap para murid-murid-Nya. Yesus benar-benar menghendaki supaya mereka mengikutiNya secara total.

Kata "mengikuti" mempunyai makna yang khusus dan mendalam. Dalam tradisi Sinoptik, mengikuti Yesus mengandung arti menjadi murid Yesus(Zannoni, 2004). Pengarang Injil Yohanes senada dengan pengarang Injil Sinoptik dalam hal penggunaan kata kerja "mengikuti”. Arti kata mengikuti ini sangat menonjol pada peristiwa pemanggilan murid-murid Yesus yang pertama, "Kedua murid itu mendengar apa yang dikatakannya itu, lalu mereka pergi mengikut Yesus” (Yoh 1:37, 40). Demikian juga dalam Yoh 8:12, “Akulah terang dunia; barangsiapa mengikut Aku, ia tidak akan berjalan dalam kegelapan, melainkan ia akan mempunyai terang hidup” dan Yoh 12:25-26, “Barangsiapa mencintai nyawanya, ia akan kehilangan nyawanya, tetapi barangsiapa tidak mencintai nyawanya di dunia ini, ia akan memeliharanya untuk hidup yang kekal. Barangsiapa melayani Aku, ia harus mengikuti Aku dan dimana Aku berada, di situ pun pelayan-Ku akan berada”, kata “mengikuti” berarti menjadi murid-Nya. Menjadi murid Yesus atau mengikuti Yesus merupakan suatu proses terusmenerus dalam hidup para murid. Murid-murid Yesus menanggapi panggilan dari Tuhan yang mengambil inisiatif terlebih dahulu melalui pemuridan, yaitu proses untuk mengikuti Yesus, sebagaimana dikatakan oleh Shirley (2008:210), "Disciples of Jesus Christ fulfill their calling through discipleship: "the process 
of following Jesus”. Murid-murid Yesus Kristus memenuhi panggilan mereka melalui pemuridan, yaitu proses mengikuti Yesus.

Dalam Injil, kita tahu bahwa Yesus memberitahukan penderitaan-Nya sampai tiga kali. Hal ini menunjukkan bahwa Yesus sudah siap dan bersedia untuk menderita. Yesus juga mengajak para murid untuk siap dan bersedia untuk menderita, sebagaimana dikatakan-Nya, "Sejak waktu itu Yesus mulai menyatakan kepada murid-murid-Nya bahwa Ia harus pergi ke Yerusalem dan menanggung banyak penderitaan dari pihak tua-tua, imam-imam kepala dan ahliahli Taurat, lalu dibunuh dan dibangkitkan pada hari ketiga” (Mat 16:21).

\subsection{PahamKemuridan}

Menjadi murid Kristus berarti mengikuti Yesus. Ketika memanggil muridmurid-Nya, Yesus mengucapkan kata-kata perintah, "Ikutlah Aku” (Mat 4:19; 8:22; Mrk 1:17; 2:14; Luk 5:27; 9:59; Yoh 1:43; 21:19). Menjadi murid Kristus yang sejati berarti mengikuti Yesus dalam menjalankan tugas dan tanggungjawabnya, ikut serta dalam pelayanan-Nya (Firmanto, 2010)(Firma, 18) dan akan tetap mengikuti Dia sampai mencapai kemuliaan-Nya. Seorang murid Yesus yang sejati akan mengikuti Yesus, seperti domba mengikuti gembalanya, pelayan mengikuti tuannya, prajurit mengikuti komandannya. Seorang murid akan mengikuti Kristus dalam menuju tujuan akhir, yaitu kemuliaan Allah. Seorang murid akan berjalan di jalan yang sama yang dilalui Kristus, dipimpin oleh RohNya, mengikuti jejak langkah-Nya, tunduk kepada perintah-perintah-Nya. Dengan kata lain, melalui pemuridan (discipleship), para pengikut Kristus dibentuk menjadi gambaran-Nya yang semakin jelas. Demikian dikatakan oleh Shirley (2008:211): "Through discipleship, followers of Jesus Christ are formed into an everclearer image of him."

Yesus menegaskan paham kemuridan yang Ia kehendaki kepada para murid-Nya. Menjadi murid-Nya atau mengikuti Dia membutuhkan komitmen total dalam hidup ini terutama ketika menghadapi penolakan dan penderitaan. Yesus juga mengingatkan para murid-Nya supaya siap dan berani menderita. Dengan demikian, siapakah murid Yesus itu pada jaman sekarang ini? Seorang murid Yesus adalah seseorang yang menerima dan membantu menyebarluaskan atau mewartakan kabar gembira Yesus Kristus. Pemuridan kristiani adalah proses pembatinan dan pertumbuhan pengajaran Yesus dan di bawah bimbingan Roh Kudus yang tinggal dalam hatinya, untuk mengatasi tekanan dan percobaan hidup sekarang ini dan menjadi semakin menyerupai Kristus (Drissi, 2019).

\subsection{Syarat-syarat Mengikuti Yesus}

Yesus menetapkan syarat-syarat mengikuti Dia atau menjadi murid-Nya, "Setiap orang yang mau mengikut Aku, ia harus menyangkal dirinya, memikul 
salibnya dan mengikuti Aku” (Mat 16:24). Yesus menekankan kesadaran penuh dan keteguhan hati atas orang-orang yang ingin menjadi murid-Nya. Menjadi murid Yesus bukan karena kebetulan, atau karena disuruh-suruh oleh orang lain, tetapi karena kehendak diri-sendiri. Apakah syarat-syarat mengikuti Yesus, Sang Guru?

Pertama-tama, adanya perubahan sikap yaitu seorang murid harus berani menyangkal dirinya, bukan menyayangkan dirinya. Seorang murid harus mengikuti Yesus dengan berani hidup tidak enak dan nyaman, karena mengikuti Yesus bukan berarti mencari enak, kesenangan, dan kenyamanan hidup. Menyangkal diri berarti mengesampingkan atau meninggalkan agenda atau rencana pribadi mereka dan melaksanakan rencana dan kehendak Tuhan.Karena mempunyai gambaran dan rencana sendiri, Petrus sunguh-sungguh menolak Yesus ditolak, menderita, dan dibunuh oleh para pemimpin agama Yahudi, tetapi itu bukan rencana Allah. Menyangkal diri berarti menyerahkan pikiran manusiawi seseorang kepada pikiran Tuhan, kepada rencana dan kehendak-Nya (Tanner, 2013). Seseorang menyerahkan diri kepada apa yang dikehendaki Tuhan, apa yang Tuhan pikirkan dan apa yang harus dilaksanakan. Seorang murid harus berani mengubah kehendaknya sendiri untuk melaksanakan kehendak Tuhan. Maka dari itu, seorang murid harus belajar mengenal apa kehendak Tuhan atas dirinya dengan membaca, merenungkan, dan melaksanakan Firman Tuhan dalam hidupnya sebagaimana dikatakan oleh Paulus, "Janganlah kamu menjadi serupa dengan dunia ini, tetapi berubahlah oleh pembaharuan budimu, sehingga kamu dapat membedakan manakah kehendak Allah: apa yang baik, yang berkenan kepada Allah dan yang sempurna” (Rom 12:2).

Seluruh hidup Yesus di dunia ini merupakan tindakan penyangkalan diri. Dalam kisah kelahiran Yesus, kita bisa tahu bagaimana Allah solider dengan manusia dengan menjadi manusia, lahir di kandang binatang, yang jelas-jelas itu bukan tempat manusia. Selama hidup dan karya-Nya, Yesus selalu dekat dengan orang-orang yang berdosa dan yang disingkirkan oleh masyarakat, dengan orangorang yang sakit, miskin, dan menderita. Di akhir hidup-Nya, Yesus mati di salib, sebuah hukuman untuk penjahat kelas kakap, sebuah kematian yang tidak terhormat. Singkatnya, seluruh hidup Yesus merupakan tindakan penyangkalan diri yang tiada putus-putusnya, sebuah tindakan yang oleh Paulus disebut sebagai pengosongan diri (kenosis), "Ia telah mengosongkan diri-Nya sendiri, dan mengambil rupa seorang hamba, dan menjadi sama dengan manusia” (Flp 2:7). Penyangkalan diri merupakan pelajaran yang sulit dan keras, dan bertentangan dengan hawa nafsu manusia dan watak daging dan darah. Setiap orang yang mau mengikuti Yesus harus berani menyangkal diri demi tujuan yang lebih mulia yaitu bersatu dengan Kristus yang dekat dengan orang-orang miskin dan menderita. Bahkan Dia menyamakan diri-Nya dengan orang-orang miskin dan menderita, 
"segala sesuatu yang kamu lakukan untuk salah seorang dari saudara-Ku yang paling hina ini, kamu telah melakukannya untuk Aku” (Mat 25:40).

Kedua, seorang murid harus berani memikul salibnya. Yesus mengharapkan murid-murid-Nya mempunyai kerelaan untuk menderita, bahkan mati sebagai martir. Apa artinya memikul salib? Kita bisa merenungkan apa yang dimaksud dengan memikul salib? Mengapa Yesus memikul salib? Apa maknanya bagi Yesus sendiri? Kita bisa melihat apa yang dikatakan oleh Paulus tentang makna memikul salib bagi Yesus sendiri: “... yang walau dalam rupa Allah, tidak menganggap kesetaraan dengan Allah itu sebagai milik yang harus dipertahankan, melainkan telah mengosongkan diri-Nya sendiri, dan mengambil rupa seorang hamba, dan menjadi manusia. Dan dalam keadaan sebagai manusia, Ia telah merendahkan diri-Nya dan taat sampai mati, bahkan sampai mati di salib (Flp 2:6-8).Paulus mengingatkan dan menekankan makna memikul salib yang dilakukan oleh Yesus sebagai wujud pengosongan diri atau merendahkan diri serendah-rendahnya. Harga salib itu sangat mahal. Dengan kata lain, harga menjadi murid Yesus atau mengikuti Yesus, sangat mahal. Seorang murid harus membayar segala-galanya dalam hidupnya untuk mengikuti jejakNya sampai di salib sebagaimana dikatakan-Nya dalam Markus 8:31-9:1 yang menyangkut kehilangan nyawa dan menyelamatkan hidup seseorang yang mau mengikut Yesus.

Lalu sekarang, apakah yang dimaksud dengan salib? Salib di sini berarti seluruh penderitaan kita, baik yang kita derita sebagai manusia maupun sebagai orang kristiani. Segala kesukaran hidup yang kita alami sebagai seorang kristiani disebut salib-salib hidup, karena kesukaran dan penderitaan yang kita alami mengingatkan kita akan kematian di atas kayu salib, yang dialami oleh Yesus karena ketaatan-Nya kepada Bapa-Nya. Seyogyanya salib Kristus membuat kita berani dan bersedia menerima berbagai kesukaran hidup kita, dan rela menderita bahkan sampai berani mati sebagai martir Kristus. Salib Kristus mengingatkan kita dan membuat kita sadar bahwa kita sama dan bersama dengan Yesus yang berani menanggung kesukaran dan penderitaan.Seseorang yang sungguh-sungguh mengikuti Yesus ke jalan salib-Nya adalah benar-benar murid-Nya yang sejati. Kalau kita hanya mengakui dan percaya kepada-Nya, tetapi tidak mengikut Yesus sampai pada salib, kita bukanlah murid-Nya. Hanya kalau kita percaya dan berani memikul salib dan mengikuti Yesus, barulah kita menjadi murid-Nya yang sejati. Dengan demikian, memikul salib kita berarti mengesampingkan tujuan, keinginan, dan ambisi pribadi kita sehingga Allah dapat mengungkapkan hasrat, kehendak, dan tujuan-Nya bagi hidup kita(Drissi, 2019). Hal ini dikatakan oleh Drissi, "Bearing our cross means putting away our personal goals, desires, and ambitions so that God can reveal his desires, ambitions, aand goals for our lives." (2019:220). 
Ketiga, seorang murid harus mengikut Yesus. Secara nyata kita bisa membaca dan meneladan orang-orang kudus, terutama para martir yang berani dan bersedia secara total mati demi Kristus(Tanner, 2013) yang diimaninya. Dalam hal memikul salib, orang-orang kudus yang menderita berani memandang Yesus, dan menerima petunjuk serta dorongan semangat dari Yesus sendiri ketika mereka menanggung penderitaan dalam hidupnya. Seorang murid Kristus harus belajar meneladani Sang Guru, bertutur kata dan bertingkahlaku sesuai dengan contoh yang diberikan oleh Tuhan Yesus. Seorang murid harus bekerja dengan benar, bahkan berani menderita karenanya. Murid yang sejati berani mengikuti sikap dan cara berpikir Yesus, ambil bagian dalam semua aktivitas dalam kehidupan Yesus sehari-hari. Inilah yang disebut mengikut Yesus.

\subsection{Makna Kemuridan}

Mengikuti Yesus berarti meneladani Dia. "Akulah jalan dan kebenaran dan hidup. Tidak ada seorang pun yang datang kepada Bapa, kalau tidak melalui Aku” (Yoh 14:6). Murid-murid Yesus adalah para pengikut Sang Jalan. Muridmurid harus percaya pada jalan dan mengikutinya. Jalan itu akan mengarahkan dan membawa kita kepada suatu tempat yang akan kita tuju, yaitu Bapa di surga. Dengan mengikuti Sang Jalan kita bisa mengetahui gambaran akan keselamatan. Keselamatan harus dicapai dengan komitmen untuk mengikuti Yesus kemanapun Dia memimpin kita. Artinya, hidup kita harus sesuai dengan hidup Yesus. Yesus adalah model, pola yang dengan bimbingan Roh Kudus membentuk kita supaya akhirnya kita menjadi serupa dengan gambaran-Nya. Allah telah menyelamatkan kita, menjadikan kita melalui kelahiran baru, dan membuat kita semua, ciptaanNya, secara istimewa memiliki hidup-Nya dan melahirkan keserupaan yang mulia. Namun kita dituntut untuk dengan penuh iman mengikuti Dia.

Seorang murid harus menjalin hubungan yang mendalam dengan Kristus, sebagaimana Kristus yang memiliki hubungan yang sangat dekat dengan BapaNya di surga (Yoh14:10). Yesus mengundang para murid-Nya untuk tinggal dan hidup bersama Yesus, “Marilah dan kamu akan melihatnya” (Yoh 1:39). Anderson dan Skinner menegaskan bahwa relasi yang mendalam dan abadi dengan Kristus adalah fondasi hidup seorang murid Kristus(Anderson \& Skinner, 2019), "an enduring relationship with Christ is the foundation of the life of a disciple”(2019:66). Seorang murid harus mengidentifikasikan dirinya dengan Kristus, menyesuaikan hidupnya dengan hidup Kristus(Kempis, 1986)Sang Guru. Artinya, seorang murid harus menyatukan diri dengan tidak terpisahkan dengan Kristus. Seorang murid menjadi sempurna kalau menyatukan dirinya dengan Kristus secara total, mengikuti Kristus kemanapun Dia berjalan, mengikuti setiap langkah-Nya (1 Ptr 2:21), dan selalu secara konstan belajar dari pada-Nya di bawah bimbingan Roh Kudus, "Disciple-making is fueled by the transformational 
work of the Holy Spirit as the Advocate whom he will send in his place" (Anderson dan Skinner, 2019:70).

Murid-murid Kristus adalah pribadi-pribadi yang taat pada Kristus meskipun di sekitar mereka ada jalan-jalan lain. Pemuridan berarti dibentuk oleh Kristus (being shaped by Christ) dan berperilaku seperti Kristus (Christ-like behavior).Santo Paulus mengatakan, “jadilah penurut-penurut Allah” (Ef 5:1) untuk menjadi pengikut Kristus dan diselamatkan. Sejak semula Yesus mengajarkan kebenaran yang sama, "Barangsiapa tidak memikul salibnya dan mengikut Aku, ia tidak dapat menjadi murid-Ku” (Luk 14:27). Seseorang tidak bisa menjadi murid Yesus, bila tidak mau memikul salib dan mengikut Dia, meskipun dia mengaku diri seorang Katolik. Seorang Katolik sejati, seorang murid Kristus adalah seseorang yang mengikuti langkah kaki Gurunya. Mengikut Yesus adalah meniru atau meneladan Dia dalam segalanya, menginternalisasikan hati dan perasaan Kritus, terlebih perbuatan-Nya, sebagaimana dikatakan oleh Paulus, "Hendaklah kamu dalam hidupmu bersama, menaruh pikiran dan perasaan yang terdapat juga dalam Kristus Yesus” (Flp 2:5).

Kita, orang-orang kristiani, yaitu para pengikut atau murid Kristus, diundang untuk setia memikul salib kita setiap hari, "Setiap orang yang mau mengikut Aku ia harus menyangkal dirinya, memikul salibnya setiap hari dan mengikut Aku" (Luk 9:23). Salib merupakan instrumen atau sarana kematian manusia lama kita, dan memungkinkan kita mengikuti Yesus dalam kebaharuan hidup sebagai pribadi baru dalam Kristus. Di dalam salib ada keselamatan, kehidupan, dan kesempurnaan hidup (Kempis, 1986). Salib merupakan sarana yang sangat dibutuhkan dimana Tuhan membentuk kita menjadi gambaran Kristus. Orang-orang Kristiani dibebaskan dari dosa dan diubah menjadi gambaran-Nya merupakan unsur-unsur pokok yang sangat menentukan hidup seorang kristiani, atau seorang murid Kristus. Maka dari itu, mengikuti Yesus merupakan esensi atau inti dari hidup kristiani (Wolfer, 2011).

Bila seseorang mau mengikut Yesus, dia harus bersatu dengan Dia dan selalu bersama-sama dengan Dia. Kesatuan dan kebersamaan dengan Yesus, diwujudkan dalam permulaan hidup kristiani yang diwujudkan dengan sakramen pembaptisan. Paulus mengungkapkan makna dari hidup bersatu dan bersama dengan Yesus: "Dengan demikian kita telah dikuburkan bersama-sama dengan Dia oleh baptisan dalam kematian, supaya sama seperti Kristus telah dibangkitkan dari antara orang mati oleh kemuliaan Bapa, demikian juga kita akan hidup dalam hidup yang baru” (Rom 6:4). Apabila kita telah disatukan dengan Dia, kita harus mengikuti-Nya. Sebaliknya, kalau kita sudah dibaptis dan dipersatukan dengan Kristus, namun kita tidak mengikuti jejak-Nya, berarti ada masalah dengan kesatuan kita bersama Kristus. Kalau kita sudah bersatu dengan 
Dia, pastilah kita akan meneladan Dia, menyesuaikan diri, pola pikir, pola hidup kita dengan pola pikir dan pola hidup Kristus, mengikuti jejak Kristus.

Makna kemuridan (discipleship) terwujud secara nyata dalam menjawab panggilan Tuhan (Mrk 1:16-20), mengikuti Kristus secara total berapapun harganya (Mat 10:34-39), mencintai sesama (Yoh 15:12-17), membentuk dan hidup dalam komunitas (Mat 18:20), dan mewartakan Injil ke seluruh penjuru dunia (Mat 28:16-20). Semuanya ini terarah kepada hidup sehari-hari menghidupi dan mewujudkan panggilan mencintai Allah dan sesama (Garner, 2019).

\section{MEMAHAMI MAKNA KESEMPURNAAN}

Manusia diciptakan oleh Allah seturut gambar dan citra-Nya. Bukan hanya diciptakan tetapi ditebus oleh Yesus Kristus dengan wafat di kayu salib. Melalui sakramen pembaptisan yang menguduskan setiap orang beriman diangkat menjadi putera-puteri Allah. Setiap orang beriman dipanggil untuk ikut ambil bagian dalan kodrat ilahi, kodrat Allah, yaitu sempurna. Setiap orang dalam status apapun dipanggil untuk hidup dalam cinta kasih sempurna kepada Allah dan sesama.

\subsection{Gagasan Kesempurnaan dalam Perjanjian Lama}

Secara etimologis kesempurnaan atau sempurna berasal dari kata Ibrani KALAL yang artinya sempurna, atau SHALAM artinya selesai, atau SHALEM yang artinya sempurna, selesai, bersifat damai sejahtera; dan kata TAMAM atau bentuk jamak TAMIM yang artinya berakhir, mencapai kesempurnaan atau sudah lengkap.

Kata TAMIM terdapat dalam Mazmur 18:31 Adapun Allah, jalan-Nya sempurna; janji Tuhan adalah murni. Kata TAMIM atau sempurna di sini mempunyai makna tidak bercacat dan tidak dapat dipersalahkan. Jika berhubungan dengan waktu, kata TAMIM ini mengandung makna selesai, komplit, berakhir seperti berakhirnya pekan atau tahun. Jika dipakai pada hal-hal yang berhubungan dengan moralitas, kata TAMIM merujuk kepada kebajikan, kebenaran, kejujuran.

Dalam kisah penciptaan, bumi merupakan salah satu karya ciptaan Allah. Pada akhir periode enam hari Allah menciptakan bumi. Allah menyatakan hasilnya "sangat baik". Alam semesta termasuk manusia di dalamnya diciptakan oleh Allah dalam kesempurnaan. Keadaan sempurna ini didapati dari pernyataan sungguh amat baik. Maka Allah melihat segala yang dijadikan-Nya itu, sungguh amat baik. Jadilah petang dan jadilah pagi, itulah hari keenam (Kej 1:31). Dari Kejadian Bab 1 ini disimpulkan bahwa Allah menciptkan langit, bumi, dan seisinya termasuk manusia di dalamnya dalam keadaan amat sangat baik atau sempurna. Bumi memenuhi standar-standar keunggulanNya yang tinggi, karena itu bumi sempurna. Namun, setelah itu Allah memerintahkan manusia untuk 
menaklukkannya, penuhilah bumi dan taklukkanlah itu (Kej 1:28). Artinya, manusia mendapat perintah untuk menguasai dan menggarap bumi dan segala isinya.

\subsection{Gagasan Kesempurnaan Dalam Perjanjian Baru}

Dalam Perjanjian Baru, gagasan sempurna atau kesempurnaan yang berasal dari bahasa Yunani TELEIOS mengandung arti sebagai berikut.

a. Menyampaikan gagasan membawa kepada kelengkapan atau kadar penuh. Dan biarkanlah ketekunan itu memperoleh buah yang matang, supaya kamu menjadi sempurna dan utuh dan tak kekurangan suatu apa pun (Yak 1:4).

b. Menjadi dewasa (Marquis, 2015), atau matang, "maturity” (Marquis, 2015: 199).Tetapi makanan keras adalah untuk orang-orang dewasa, yang karena mempunyai pancaindera yang terlatih untuk membedakan yang baik dari pada yang jahat (Ibr 5:14).

c. Telah mencapai akhir, tujuan, atau target yang tepat atau yang ditentukan. Sesudah itu, karena Yesus tahu, bahwa segala sesuatu telah selesai (Yoh 19:28); Bukan seolah-olah aku telah memperoleh hal ini atau telah sempurna, melainkan aku mengejarnya, kalau-kalau aku dapat juga menangkapnya, karena aku pun telah ditangkap oleh Kristus Yesus (Flp 3:12).

Hanya Allah, Sang Pencipta yang memiliki kesempurnaan dalam pengertian yang mutlak. Sedangkan Tuhan Yesus adalah gambar Allah yang tidak kelihatan, "an image of the invisible God" (Cochran, 2009: 409). Tuhan Yesus mengatakan mengenai kualitas kesempurnaan dari kebaikan Allah: "Tak seorangpun yang baik dari pada Allah saja” (Mrk 10:18). Kesempurnaan dan kebaikan Allah itu terwujud secara nyata dalam diri Yesus Kristus(Cochran, 2009) sebagai gambar Allah yang murni, "Christ is the original imago Dei" (Cochran 2009: 412).

\subsection{Kesempurnaan Yesus}

Dengan hadirnya Allah ke dalam dunia, menjadi manusia Yesus Kristus, Allah telah memenuhi janjiNya akan Juru selamat dari dosa. Hal ini sudah dinyatakan banyak sekali dalam Perjanjian Lama. Misalnya, dalam kitab nabi Yesaya dikatakan: Aku, Akulah Tuhan dan tidak ada juru selamat selain daripadaKu (Yes 43:11).

Dalam percakapan antara Malaikat Gabriel dan Maria dalam peristiwa pemberitahuan tentang kelahiran Yesus, kita bisa melihat bahwa Yesus Kristus dilahirkan sebagai manusia yang sempurna, yaitu kudus, dan tanpa dosa. Jawab malaikat itu kepadanya: "Roh Kudus akan turun atasmu dan kuasa Allah yang 
Mahatinggi akan menaungi engkau; sebab itu anak yang akan kaulahirkan itu akan disebut kudus, Anak Allah (Luk 1:35). Kesempurnaan fisiknya tentu saja bukannya tak terhingga melainkan di dalam lingkup manusia. Dalam pengosongan diri-Nya sebagai manusia, Yesus mengalami keterbatasan sebagai manusia. Yesus bisa menjadi letih (Mrk 4:36-39; Yoh 4:6), haus (Yoh 4:7), marah (Yoh 2:13-15), dan lapar (Mat 4:2). Bahkan Yesus pun mengalami kematian (Mrk 15:37, 44-45).

Meskipun menjadi manusia seperti kita, Yesus Kristus tidak berdosa dan tidak pernah berbuat dosa. Karena itu Allah mengorbankan Yesus Kristus sebagai pengganti kita yang sempurna. Dia menanggung hukuman yang sepantasnya kita tanggung yaitu kematian. Dia yang tidak mengenal dosa telah dibuatNya menjadi dosa karena kita, supaya dalam Dia kita dibenarkan oleh Allah (2 Kor 5:21). Jika kita menanggung dosa kita sendiri, kita akan menderita di dalam neraka. Allah memegang janjiNya dengan mengutus dan mengorbankan Anak Tunggal-Nya yang menanggung dosa-dosa dari orang-orang yang percaya kepadaNya. Inilah kesempurnaan kasih Allah kepada manusia.

Karena kesempurnaan-Nya, Ia menjadi Imam Besar demi kepentingan umat manusia. Sebagai sang Imam yang menjadi perantara bagi umat, Ia telah menjadi seperti suadara-saudara-Nya dalam segala hal, Ia mengalami penderitaan, Ia pun belajar ketaatan di bawah ujian, sebagaimana yang dialami semua manusia atau para pengikut jejakNya. Dengan demikian, Ia dapat bersimpati terhadap kelemahan-kelemahan kita, pribadi yang telah diuji dalam segala hal seperti kita sendiri, namun Ia tetap tanpa dosa (Ibrani 2:10-18; 4:15; 5:7-10). Sebab Imam Besar yang kita punya, bukanlah imam besar yang tidak dapat turut merasakan kelemahan-kelemahan kita, sebaliknya sama dengan kita, Ia telah dicobai, hanya tidak berbuat dosa (Ibr 4:15).

\subsection{Kesempurnaan Berpuncak pada Kurban Salib Yesus Kristus}

Dalam kisah sengsara Yesus, terutama di pengadilan, Yesus menunjukkan diriNya sebagai orang yang tidak berdosa. Sebelum disalibkan, Yesus pernah diadili sebanyak enam kali. Di kalangan mereka adalah para pemimpin masyarakat Yahudi, para penguasa Roma, para imam dan guru Taurat, tetapi tidak satupun yang dapat membuktikan dosa yang telah dilakukan oleh Yesus. Pilatus, gubernur kerajaan Roma berkata tiga kali, "Aku tidak mendapati kesalahan apapun pada-Nya” (Yoh 18:38b). Sebenarnya Pilatus berkeinginan untuk membebaskan Yesus, namun karena hasutan orang-orang Yahudi dan teriakan mereka yang memohon agar Yesus disalibkan, Pilatus melihat bahwa katakatanya sia-sia saja. Pilatus mengambil air lalu membasuh tangannya di hadapan orang banyak dan berkata, "Aku tidak bersalah terhadap darah orang ini; itu 
urusan kamu sendiri!” (Mat 27:24). Lalu Pilatus menyerahkan Yesus untuk disalibkan.

Yesus Kristus yang sungguh manusia dan sungguh Allah, mempunyai kodrat ilahi dan manusiawi. Kemanusiaan Yesus terlihat dalam sifat dan karakter kemanusiaan Yesus yang dilahirkan dan mengalami perkembangan hidup seperti manusia, kecuali dalam hal dosa. Keilahian Kristuslah atau Kristus yang memiliki cinta dan kebebasan Ilahi (divine Freedom) (McFarland, 2017)yang membuatNya tak dapat berbuat dosa karena: pertama, imunitasNya, yaitu identitas diri-Nya yang tak pernah berubah, “... tetapi Engkau tetap sama, dan tahun-tahun-Mu tidak berkesudahan." (Ibrani 1:12). Ia tetap kudus dan sempurna baik dulu, sekarang dan selama-lamanya, "Yesus Kristus tetap sama, baik kemarin maupun hari ini dan sampai selama-lamanya" (Ibr 13:8); kedua, kekuatanNya (Omnipotence), yang membuat Yesus tidak bisa jatuh ke dalam dosa.Jatuh ke dalam godaan menunjukkan suatu kelemahan moral atau kurangnya suatu kekuatan. Kristus mempunyai kuasa yang besar dan karena tidak dapat jatuh ke dalam dosa; ketiga, kemahatahuan-Nya (Omniscience)- Iblis menjatuhkan kita dengan cara menipu kita, tapi Yesus mempunyai pengetahuan ilahi sehingga Ia tidak dapat ditipu.

Yesus Kristus bukan hanya Kudus tanpa dosa, namun Ia pun berkuasa memberi kekudusan karena Ia berkuasa mengampuni dosa: Ketika melihat iman mereka, berkatalah Ia kepada orang lumpuh itu: "Hai anakKu, dosamu sudah diampuni!” (Mrk 2:5).

Namun sungguh ironis, kesempurnaan Yesus akhirnya justru terpenuhi dalam peristiwa manusiawi yang mengharukan dan menjijikan yaitu pada peristiwa salib. Kristus memilih kematian-Nya di atas kayu salib sebagai hukuman mati yang paling keji dan biadab untuk menunjukkan kesempurnaan kasih Allah yang paling radikal(Dreyer, 2000) kepada umat manusia yang berdosa. "Christ chose death by crucifixion in order to demonstrate in the most radical-way possible the completeness of his love for humanity" (Dreyer, 2000:29). Kesempurnaan kasih Allah terpenuhi dengan pengurbanan Yesus yang sempurna di atas kayu salib.

\section{MEWUJUDKAN HIDUP MENUJU KESEMPURNAAN}

Tuhan Yesus mengajar bagaimana menjadi sempurna (Mat 5:43-48). Karena itu haruslah kamu sempurna, sama seperti Bapamu yang di surga adalah sempurna (Mat 5:48). Karena peristiwa inkarnasi, Sabda menjadi manusia dalam Yesus Kristus, manusia ciptaan Allah ini dimungkinkan untuk mencapai kesempurnaan atau dimampukan untuk menjadi sempurna atau menjadi kudus(Cochran, 2009)seperti Allah sendiri. Bagaimana kita harus hidup menuju kesempurnaan atau menjadi sempurna menyerupai Allah Bapa? 
Pertama, sebagaimana kata sifat teleios adalah bentukan dari kata benda telos, yang berarti akhir, tujuan, maksud, dan hasil,maka dari itu, menjadi muridmurid Yesus yang hidup menuju kesempurnaan pertama-tama harus hidup sesuai dengan tujuan penciptaan manusia, sebagaimana dikatakan dalam Kitab Kejadian: “Baiklah kita menjadikan manusia menurut gambar dan rupa kita” (Kej 1:26). Alkitab mengisahkan bahwa manusia diciptakan untuk menjadi segambar dan serupa dengan Allah.Penciptaan manusia yang secitra dan segambar dengan Allah memampukan manusia untuk berpartisipasi dalam kebaikan dan kesempurnaan Allah, "Our creation in God's image thus enables us to participate in God's goodness” (Cochran, 2009: 403). Apa artinya menjadi segambar dan serupa dengan Allah? Manusia harus mirip atau seperti Allah dengan melakukan kasih yang tanpa pamrih, yang penuh kebajikan tanpa batas dan demi kebaikan semata. Allah menciptakan manusia menurut citra dan keserupaan-Nya. Dengan memanggilnya untuk berada karena cinta, sekaligus Allah memanggil manusia untuk cinta(Paus Yohanes Paulus II, 1999).

Kedua, hidup menuju kesempurnaan berarti hidup menyerupai Allah. Kita dituntut untuk belajar memberikan apa yang paling berharga yang kita miliki. Kita dapat mulai dengan tindakan tanpa pamrih yang mencengangkan ini yang datang langsung dari hati Bapa, sebagaimana dikatakan dalam Yohanes 3:16, "Karena begitu besar kasih Allah akan dunia ini, sehingga Ia telah mengaruniakan AnakNya yang tunggal, supaya setiap orang yang percaya kepada-Nya tidak binasa, melainkan beroleh hidup yang kekal”. Menyerupai Allah dalam hal ini berarti mencintai sebagaimana Allah mengasihi, karena Dia mengasihi kita sampai pada harga yang harus dibayar-Nya, apa yang paling berharga bagi-Nya.

Ketiga, hidup menuju kesempurnaan berarti belajar mengasihi mereka yang tidak mencintai kita.Dalam menyerupai-Nya, kita perlu melihat bahwa kasih Allah yang luar biasa dalam memberikan Anak-Nya, adalah kasih yang dicurahkan bukan hanya bagi mereka yang mengasihi Dia tetapi juga untuk "seluruh dunia”, Dan Ia adalah pendamaian untuk segala dosa kita, dan bukan untuk dosa kita saja, tetapi juga untuk dosa seluruh dunia (1Yoh 2:2) termasuk yang tidak mengakui Dia, yang menolak Dia, dan yang berseteru dengan-Nya! Demikian juga Tuhan tidak hanya memberikan hujan dan sinar matahari kepada yang jahat dan yang baik. Karena dengan demikianlah kamu menjadi anak-anak Bapamu yang di sorga, yang menerbitkan matahari bagi orang yang jahat dan orang yang baik dan menurunkan hujan bagi orang yang benar dan orang yang tidak benar (Mat5:45). Bahkan Allah Bapa kita memberikan "Anak-Nya yang tunggal” kepada dunia. Untuk bisa menyerupai dan mengikuti Dia, kita harus selalu mohon rahmat-Nya agar Allah mengubah hati kita supaya hati kita semakin menyerupai hati Allah Bapa. 
Keempat, hidup menuju kesempurnaan berarti hidup saling mengasihi tanpa pamrih. Sebagai guru yang unggul dan berbeda dari guru-guru atau rabi-rabi Yahudi pada jaman itu, Yesus memberikan pengajaran yang sangat menarik, baik cara penyampaiannya maupun isi pengajaran-Nya. Tuhan Yesus menyampaikan materi pengajaran yang berbeda dari standar-standar umum mengenai moral yang dianut di dalam dunia dengan standar yang harus dituju dan dipenuhi oleh muridmuridNya. Pengajarannya itu harus dilaksanakan dan yang harus menjadi ciri dari murid-muridNya seperti yang dikatakan-Nya, "Dengan demikian semua orang akan tahu, bahwa kamu adalah murid-murid-Ku, yaitu jikalau kamu saling mengasihi” (Yoh 13:35). Kasih yang dimaksudkan-Nya adalah kasih yang bukan berdasarkan perasaan subyektif satu dengan yang lain, tetapi berdasarkan identitas timbal-balik mereka sebagai anggota tubuh Kristus (Shirley, 2008).

Bahwa prinsip suatu perbuatan baik harus dibalas dengan suatu perbuatan baik pula, ini dianut oleh orang-orang yang kurang saleh bahkan orang-orang kafir. Siapa saja yang membalas perbuatan baik dengan perbuatan jahat itu dianggap kejam dan tidak senonoh. Namun murid-murid Yesus tidak boleh puas dengan standar-standar konvensional mengenai tingkah laku yang umum itu saja. Lebih dari itu, Yesus Kristus meletakkan bagi murid-muridNya, sebuah perbuatan jahatpun patut menerima sebuah perbuatan baik.

Kata patut bukanlah kata yang tepat. Satu perbuatan jahat mungkin patut menerima pembalasan satu perbuatan jahat pula, tetapi satu perbuatan jahat terhadap muri-murid Yesus haruslah dibalas dengan perbuatan baik. "Dan apabila kamu memberi salam kepada saudara-saudaramu saja, apakah lebihnya dari pada perbuatan orang lain? Bukankah orang yang tidak mengenal Allah pun berbuat demikan?” (Mat 5:47). Dan langsung setelah itu, datanglah perkataan: "Karena itu haruslah kamu sempurna, sama seperti Bapamu yang di surga adalah sempurna” (Mat 5:48).Ini memang terdengar bagai nasehat tentang kesempurnaan dalam arti yang harafiah. "Menjadi sempurna seperti Allah”? siapa yang bisa mencapai kesempurnaan seperti Allah? Apakah bukan cuma buangbuang waktu meskipun kita baru untuk mencobanya saja?Namun konteks perkataan ini menolong kita untuk memahami ketegarannya. Mengapakah muridmurid Tuhan Yesus, para ahli waris Kerajaan Allah harus membalas kejahatan dengan kebaikan?

Dalam Hukum Taurat disebutkan: “Kasihilah sesamamu manusia seperti dirimu sendiri" (Imamat 19:18), tetapi kegenapan perintah itu tergantung dari jawaban atas pertanyaan “Siapakah sesamaku manusia?” (Luk 10:29). Ketika Yesus mendapat pertanyaan itu, Ia menceritakan kisah tentang orang Samaria yang baik hati untuk menunjukkan bahwa sesamaku dalam arti yang dimaksudkan oleh perintah itu ialah siapapun yang memerlukan pertolongan, siapapun yang bisa aku layani dengan ramah. Hal ini juga sangat ditekankan oleh Paus 
Fransiskus bahwa seorang murid harus setia kepada Sang Guru. Dalam diri orangorang yang lemah dan miskin itu kita semakin mengenal Kristus dan semakin memiliki belas kasih atau hati seperti Kristus sendiri (GE, 96), "sebab belas kasihan adalah denyut hati Injil” (GE, 97).

Tetapi orang-orang Israel pertama-tama yang diberi perintah itu tidak menganggap orang Kanaan sebagai sesama dalam arti harus dikasihi. Dan keturunan mereka di jaman Perjanjian baru tidak menganggap seorang Romawi, atau seorang Samaria, dan semua orang non-Yahudi sebagai sesama pula. Kebanyakan sistem etika menekankan kewajiban seseorang kepada sesamanya; tetapi gerak maju dalam etika ditandai oleh wawasan yang meluas. Yang terkandung dalam jawaban atas pertanyaan "Siapakah sesamaku manusia? Mengapakah aku harus ramah kepada orang yang tidak ramah kepadaku? Bila seseorang berbuat jahat kepadaku, mengapa aku tidak boleh membalas kejahatan yang setimpal dengan apa yang diperbuatnya? Karena Tuhan Yesus Allah sendiri memberi teladan dalam hal ini, yaitu "Bapamu yang di surga yang menerbitkan matahari bagi orang yang jahat dan orang yang baik dan menurunkan hujan bagi orang yang benar dan orang yang tidak benar" (Mat 5:45).Allah mencurahkan berkatNya tanpa pilih bulu, tanpa diskrimasi. Pengikut Tuhan Yesus adalah anakanak Allah sehingga mereka ini harus memancarkan kemiripan keluarga dengan berbuat baik kepada semua orang tanpa pandang bulu dan tanpa diskriminasi pula. Maka, sebagai anak-anak Allah mereka harus menjalani jalan yang sempurna dalam melakukan perbuatan baik, sama seperti Allah yang menjadi Bapa bagi umat manusia. Perintah yang sama muncul dalam konteks yang serupa, tetapi dalam kata-kata yang sedikit berbeda, yaitu: Hendaklah kamu murah hati, sama seperti Bapamu adalah murah hati” (Luk 6:36).Perintah Tuhan Yesus tidak sulit untuk dipahami, namun sulit untuk dilakukan. Jadilah anak-anak Allah yang mencerminkan kasih yang sempurna dari Bapa kita di surga.

Allah dipandang sebagai ideal kesempurnaan yang harus ditiru dan dikejar oleh orang-orang yang mengikuti atau menjadi murid Yesus. Pengikut atau murid Yesus tidak boleh berpuas diri dengan hanya bisa melakukan hukum atau aturanaturan keagamaan mereka (Mat 5: 20, 48), melainkan mereka harus mengasihi sesama manusia(Leon-Dufour, 2014), terutama orang-orang miskin dan menderita sebagaimana dikatakan Yesus, "jikalau engkau hendak sempurna, pergilah, juallah segala milikmu dan berikanlah itu kepada orang-orang miskin, maka engkau akan beroleh harta di surga, kemudian datanglah kemari dan ikutlah Aku” (Mat 19:21).

Kesempurnaan hidup bukanlah sesuatu yang abstrak. Pengalaman hidup dengan Tuhan secara nyata dapat diwujudkan dalam hidup bersama sesama manusia yang miskin dan menderita, dimana Yesus mengindentifikasikan diriNya sebagai orang yang miskin dan menderita.Santo Vinsensius mendorong kita 
semua untuk meneladan Yesus mewartakan Injil kepada orang miskin dengan kata-kata dan perbuatan sebagai cara yang paling sempurna. Hal ini dikatakannya dalam suratnya:

Jika di antara kita ada yang berpikir bahwa tugas kita hanya untuk mewartakan Injil kepada kaum miskin, dan bukan untuk meringankan penderitaan mereka, hanya untuk memenuhi kebutuhan rohani dan bukan kebutuhan jasmani mereka, maka saya menegaskan bahwa kita harus menolong mereka dan memastikan bahwa mereka ditolong dengan segala cara, baik oleh kita sendiri maupun oleh orang-orang lain. Melakukan hal ini berarti mewartakan Injil baik dengan kata-kata maupun dengan perbuatan-perbuatan. Inilah cara yang paling sempurna.(SV. XII, 87).

\section{KESIMPULAN}

Setiap orang Kristen yang dipanggil untuk menjadi murid Kristus harus berani menyangkal dirinya sendiri, memikul salibnya setiap hari, dan mengikuti Yesus, Sang Guru Agung. Panggilan mengikuti Kristus ini membawa konsekuensi untuk secara dinamis hidup menuju kesempurnaan. Pikiran, pola hidup, kata dan perbuatannya sesuai dengan pola pikir, pola hidup, kata dan perbuatan Yesus Kristus. Sebagaimana kesempurnaan Yesus, Sang Gambar Allah yang tak kelihatan, dipenuhi dalam ketaatan-Nya kepada Bapa-Nya dengan mati di kayu salib, seorang murid Kristus juga harus berani mengurbankan diri untuk kepentingan sesama dalam bimbingan Roh Kudus untuk menuju kesempurnaan hidupnya.

\section{DAFTAR PUSTAKA}

Anderson, Tamara L \& Skinner, Shelly A., 2019, "Feelings: Discipleship that Understands the Affective Processes of a Disciple of Christ”, Christian Educational Journal, Glen Ellyn Vol 16, April, 66-78.

Cochran, Elizabeth A., 2009, "The Imago Dei and Human Perfection: The Significance of Christology for Gregory of Nyssa's Understanding of the Human Person”, The Heythrop Journal Vol. 50 Issue 3, 402-415.

Dreyer, E.A., 2000, The Cross in Christian Tradition, New Jersey: Mahwah: Paulist Press.

Drissi, Ani G., 2019, "What is Transforming Discipleship”, World Council of Churches: The Ecumenical Review, Vol. 71, No. 1-2, 216-224.

Firmanto, Denny A., 2010, Menggerakkan Jemaat: Pemuridan Menurut Injil Markus. Malang: Penerbit Dioma. 
Garner, S., 2019, Imaging Christ in Digital Worlds: Continuity and Discontinuity in Discipleship, Communication Research Trends, 38 (4), 21 - 30.

Kempis, Thomas a., 1986, Mengikuti Jejak Kristus terjemahan J. O. H Padmasepoetra, Pr. Jakarta: Obor.

Leon-Dufour, Xavier, 2014, Ensiklopedi Perjanjian Baru. Yogyakarta: Kanisius.

Marquis, Timothy L., 2015, "Perfection Perfected:The Stoic "Self-Eluding Sage" and Moral Progress in Hebrews", Novum Testamentum 57, 187-205.

McFarland, Ian A., 2017, "Present in Love: Rethinking Barth on the Divine Perfections”, Modern Theology 33, 243-258.

Shirley, Christ., 2008, "It Takes a Church to Make a Disciple: An Integrative Model of Discipleship for the Local Church", Southwestern Journal of Theology, Volume 50, Number 2, Spring, 207-224.

Tanner, Paul., 2013, “The Cost of Discipleship: Losing One's Life for Jesus' Sake”, Journal of the Evangelical Theological Society 56/1, 43-61.

Wolfer Terry A., 2011, "Following Jesus in Social Work: Learning from Anabaptist Theology and Practice", Journal of North American Association of Christians in Social Work Vol. 38, No. 2, 146-174.

Yohanes, P. II., 1999. Menuju Kesempurnaan Ilahi: Yubelium Agung 2000. Yogyakarta: Kanisius

Zannoni, Arthur E., 2004, Jesus of the Gospel: Apa Kata Injil tentang Dia, Jakarta: Obor. 